\title{
Raised in the wild south: a dendrochronological and dendrochemical profile of a far-southern stand of kauri (Agathis australis) on the Taieri Plain, Otago
}

Tom H Brookman ${ }^{1 *}$, Gregory A Steward ${ }^{2}$, Jonathan G Palmer ${ }^{3}$, Pavla Fenwick ${ }^{4}$, Austen H Banks ${ }^{5}$ and Travis W Horton'

\begin{abstract}
Background: Kauri (Agathis australis (D.Don) Lindl.) is endemic to New Zealand and is the southernmost species of the tropical genus Agathis.

Methods: The growth history of the second southern-most known stand of New Zealand kauri is documented. This stand is located at Wairongoa Springs near Dunedin, approximately $8^{\circ}$ of latitude south of the modern natural range of the species. This stand was established in the 1950s and now approximates a natural 'ricker' stand of juvenile kauri. Sample plot measurements of height and diameter growth taken in 2009 were compared to published 1986 data from the same stand, and were used for modelling self-thinning dynamics. An investigation was also undertaken using ring-widths from cores obtained by increment boring to generate a 52-year dendrochronological record that shows a strong common pattern of long-term and inter-annual changes in growth. Carbon isotope analysis of annual rings from 1983-2009 revealed corresponding multi-decadal chemical trends. Segmented linear regression was used to compare the ring-width record with existing kauri growth and self-thinning models.

Results: Growth of kauri at Wairongoa Springs was fast, was comparable to other plantations of kauri without silvicultural tending, and was generally faster than that of natural stands. The growth of the stand can be considered as occurring in two apparent phases. The first was a 26-year period of relatively constant rapid growth with ring-widths averaging $3.5 \mathrm{~mm}$ while the second phase showed a steady decline in annual growth thought to be indicative of self-thinning due to increasing competition. This ring-width decline was matched by a gradual decline in the ratio of carbon isotope ${ }^{13} \mathrm{C}$ to ${ }^{12} \mathrm{C}$.

Conclusions: Ring-width measurements and carbon isotope determinations compared with forestry-based modelling of self-thinning in kauri suggest that this stand is undergoing self-thinning much sooner than other kauri stands. This result highlights other possible influences beyond simple biomass accumulation triggering the onset of self-thinning. The growth rate of the plantation is comparable to others from the North Island, demonstrating that kauri can be grown, albeit in sheltered sites, throughout the length of New Zealand.
\end{abstract}

Keywords: Agathis australis; Kauri; Plantation; Growth-rate; Self thinning; Dendrochronology; Ring-width; Carbon isotopes

\footnotetext{
* Correspondence: thb29@uclive.ac.nz

${ }^{1}$ Department of Geological Sciences, University of Canterbury, Private Bag

4800, Christchurch 8140, New Zealand

Full list of author information is available at the end of the article
} 


\section{Background}

\section{Kauri ecology and growth}

New Zealand kauri (Agathis australis (D.Don) Lindl.) is a canopy-emergent tree that can reach heights of 30-60 m when mature (Ecroyd 1982). It generally has a straight, cylindrical trunk clear of branches for 12-25 m (Bergin and Steward 2004). The largest living kauri, Tāne Mahuta (based on estimated wood volume), is $\sim 4.5 \mathrm{~m}$ in diameter and over $50 \mathrm{~m}$ high (Bergin and Steward 2004; Stewart 2008). Before extensive logging and gum-harvesting operations in the $19^{\text {th }}$ and $20^{\text {th }}$ centuries, kauri were often larger, with the largest officially measured, Kairaru, being over twice the size (timber volume in $\mathrm{m}^{3}$ ) of Tāne Mahuta, with a diameter of $\sim 6.4 \mathrm{~m}$ (Wardle 2011). Typical longevity is thought to be approximately 600 years (Ahmed and Ogden 1987) and, while recent estimates suggest that maximum ages are probably generally in the order of 1500-1700 years (Steward and Beveridge 2010), some individuals may exceed 2000 years of age (Palmer et al. 2006). This longevity makes kauri a useful resource for tree-ring studies into past climates (i.e. dendroclimatology); New Zealand has an exceptional dendrochronological record, compiled from living and sub-fossil kauri (Boswijk et al. 2006; Palmer et al. 2006; Turney et al. 2010).

One of the limitations of kauri for dendroclimatic study is that it currently only naturally occurs in the north of New Zealand, from approximately Te Puke/ Kawhia $\left(\sim 38^{\circ} \mathrm{S}\right)$ to Cape Reinga $\left(\sim 34^{\circ} \mathrm{S}\right)$. Despite this, planted kauri grow successfully in numerous areas outside their natural range (Pardy et al. 1992). There are individual specimens or small groups growing as far south as Invercargill $\left(\sim 46.5^{\circ} \mathrm{S}\right)$ and even Stewart Island $\left(\sim 47^{\circ} \mathrm{S}\right)$, and kauri are routinely planted as ornamental trees around the country (Niinemets et al. 2005). Their success in planted stands throughout New Zealand is less surprising after looking at the fossil record. Early records of kauri showed the species occurring in geographically and climatically distinct environmental conditions to the modern day. For example, Lee et al. (2007) reported leaf macrofossils in Southland during the late Oligocene-early Miocene, and Evans (1937) identified kauri resin in fossilised material in Tertiary lignite deposits from the Roxburgh $\left(\sim 45.5^{\circ} \mathrm{S}\right)$ and Mataura $\left(\sim 46^{\circ} S\right)$ areas in the South Island. Araucarian ancestors of kauri first appeared in the Cretaceous period (Lee et al. 2007). More relevant to the current distribution of kauri, however, are the findings of Mildenhall (1985), who noted extensive palynological evidence of kauri around 300,000 BP (before present) at Lower Hutt in Wellington $\left(\sim 41^{\circ} \mathrm{S}\right)$, a period during which southern hemisphere climate was significantly cooler than at present (Petit et al. 1999; Jouzel et al. 2007). Pleistocene evidence of a more extensive distribution for kauri (Ecroyd 1982) has led numerous authors to speculate on the causes of the failure of this species to recolonise land further south in recent times (e.g. Mitchell 1991; Ogden et al. 1992, 1993). A number of reasons have been suggested, including climatic limitation, lack of suitable soils and terrain, and simply slow expansion due to episodic stand regeneration (Ogden et al. 1992; Steward and Beveridge 2010). Recent permanent regeneration from planted stands south of the current natural limit suggest that kauri may only just be in a process of extending its range, recently curtailed by the episodic glaciations of the Quaternary period (Steward et al. 2003).

The study of species outside their natural limits is important to the long-term prospects of planted forests of indigenous species in New Zealand. The reputations of many New Zealand indigenous species for producing high-quality timber were based on the use of heartwood from mature specimens logged from old-growth indigenous forests. To replicate these qualities, many species may require long plantation rotations (McConchie 1999). Even those species, like kauri (Steward and McKinley 2005), from which high-quality sapwood can be utilised, are estimated to take 2-3 times as long as commonly planted species like Pinus radiata D.Don to reach harvestable proportions. Consequently, more data on plantation density and thinning is required for effective long-term plantation management, so continued monitoring of plantations as they near their suggested harvest age $(\sim 80$ years for kauri (Chikumbo and Steward 2007)) is vital. The ability to extend the geographical boundaries of a given species is another area that requires further research. Some species are likely to grow well in areas beyond their current natural limits, based on climatic and soil profiling of their preferred habitat (Burns 1999). This point is illustrated for kauri by Bergin and Steward (2004) in their review of various Agathis species grown as planted forests outside their natural ranges. These include Australian Agathis robusta (C. Moore) F.M. Bailey, which is now grown more successfully outside its natural range (e.g. South Africa) than within it due to the lack of insect predation in other areas. In the New Zealand context, the successful establishment and growth of kauri at Wairongoa Springs near Dunedin (approximately $8^{\circ}$ of latitude south of its modern natural range; see Section 1.2) is evidence that kauri can be grown well south of its current distribution. Early surveys suggest that the same may be true of other species including puriri (Vitex lucens Kirk) and kohekohe (Dysoxylum spectabile (G.Forst.) Hook.f.) (Pardy et al. 1992), identified by multiple authors as having hardwood plantation potential (McConchie 1999; Steward 1999).

This study aims to update and augment the earlier published profile (Pardy et al. 1992) of the Wairongoa Springs site. Burns (2009) recently called for a renewal of New Zealand-based research into forest management of indigenous species, citing a dearth of new research particularly in the fields of plantation establishment and 
management. A combination of methods was employed to characterise growth in kauri growing at Wairongoa Springs. Data from a sample plot used for growth measurements and modelling are augmented with a dendrochronological ring-width measurement approach to assess growth rates and patterns in individual trees. These data are compared with a short dendrochemical (carbon stable isotope) chronology from the site. The inclusion of the Wairongoa Springs site in a broader research programme aimed at establishing the potential of New Zealand indigenous trees as dendrochemical indicators of climate change facilitated the collection of relevant data. The application of a dendrochemical record here is a novel approach to characterising growth processes in plantations of New Zealand indigenous trees.

Commonly, inter-annual growth changes in tree-rings are used to reconstruct climatic changes influencing treegrowth but such dendroclimatic studies tend to avoid juvenile trees due to the strong age-dependent influences on growth (Fritts 1976). Dendrochronology, the counting and measurement of annual growth rings, is also commonly used in forestry as a means of analysing changes in growth throughout the life of plantation trees on annual to longterm scales. This is particularly useful in situations where a lack of regular monitoring means that detailed growth records cannot be retrieved from external diameter-based measurements (e.g. Baskerville 1972).

The ratio of two stable isotopes of carbon $\left({ }^{13} \mathrm{C}\right.$ and $\left.{ }^{12} \mathrm{C}\right)$ in tree rings provides a record of the balance between stomatal conductance and photosynthetic rate for that tree (Farquhar et al. 1982; Francey and Farquhar 1982). Consequently, this ratio can be used to assess physiological changes in the photosynthetic systems of trees that relate to water-use efficiency (Stephens et al. 1999; Farquhar and Richards 1984; Farquhar et al. 1982) and changes in light availability/photosynthetic performance (Walcroft et al. 2002; Farquhar et al. 1982, 1989; Francey and Farquhar 1982). Stable isotopes in young trees from a number of environments are generally observed to exhibit a 'juvenile effect', with $\delta^{13} \mathrm{C}$ (the relative abundance of ${ }^{13} \mathrm{C}$ to ${ }^{12} \mathrm{C}$ ) increasing with tree age (see McCarroll and Loader 2004 and references therein for a review of the juvenile effect and a detailed review of carbon isotope theory; Leavitt 2010). This same trend has been observed in early rings of mature kauri (Jansen 1962; Grinsted and Wilson 1979). However, the mechanisms behind the 'juvenile effect' are poorly understood and have been variously ascribed to numerous sources including increased light availability as trees grow (Francey and Farquhar 1982) and a reduction in the photosynthetic use of canopy-respired $\mathrm{CO}_{2}$ as trees grow (Schleser and Jayasekera 1985). However, as yet, there is no consensus in the literature on a single cause that fits the diverse range of environments in which the juvenile effect has been identified (Leavitt 2010). In this study, carbon isotopes were used to assess whether that pattern is evident in plantation kauri.

\section{History of the Wairongoa Springs site}

Wairongoa Springs is a property on the north-eastern margin of the Taieri Plain near Dunedin. It was owned in the late $19^{\text {th }}$ and early $20^{\text {th }}$ centuries by the Thomson family, proprietors of Thomson \& Co. cordial manufacturers. The Wairongoa Springs site provided much of the naturally carbonated spring water for their beverages, from springs that still flow today. Indeed, many of the business's original buildings still stand on the property, within $100 \mathrm{~m}$ of the kauri. Mr A.C.B. Thomson, son of the proprietor, Alexander Thomson, lived on the property upon his return from the First World War as a somewhat reclusive and eccentric local character. He was a botanist and horticulturalist who established an extensive arboretum on the property, including around 110 juvenile kauri trees planted between 1955 and 1957 (Unknown 1964). It is possible that the kauri stock originated from New Plymouth as Mr Thomson Jr was in contact with Duncan and Davies Ltd, seed merchants there (letter from V.C. Davies to A.C.B. Thomson, $11^{\text {th }}$ February 1957); flourishing kauri plantations had already been established in New Plymouth by another botanist, Fred Cowling. Cowling had established the Brooklands Park and Fred Cowling Reserve kauri plantations in New Plymouth ( 1935) (Herbert et al. 1996). It is highly likely that the New Plymouth stock, and therefore the Wairongoa Springs stock, originated from Waipoua Forest (Steward 2011, Barton personal communication). At the time, the Waipoua nursery was the only commercial source of kauri seed, originally collected from 17 trees between 1951-54 (Morrison 1955) and then rapidly expanded until, in 1972, 94 trees were being harvested (Morrison and Lloyd 1972). At the time of initial sampling in the current study, approximately 60-70 of Thompson's trees still thrived, constituting probably the largest kauri stand in the South Island. However, a number of trees were severely damaged in a strong northwesterly wind event shortly before the second sampling trip, (Figure 1).

\section{Methods}

The site, referred to henceforth as Dunedin Kauri (DK), is situated amongst gently rolling hills on the north-eastern margin of the Taieri Plain, at an elevation of $\sim 46 \mathrm{~m}$ above sea level (asl) (45.833 S, 170.3614 E) (Figure 2). Although less than $30 \mathrm{~km}$ from the coast, the Taieri Plain has a microclimate created by shelter from hills to the east and the Silver Peaks Range to the north and northeast (Unknown 2001). The nearby town of Invermay receives $\sim 730 \mathrm{~mm}$ of annual rainfall and has a mean annual temperature of $\sim 10.3^{\circ} \mathrm{C}$ (CliFlo - The National Climate Database 2011). Rainfall is relatively uniform 


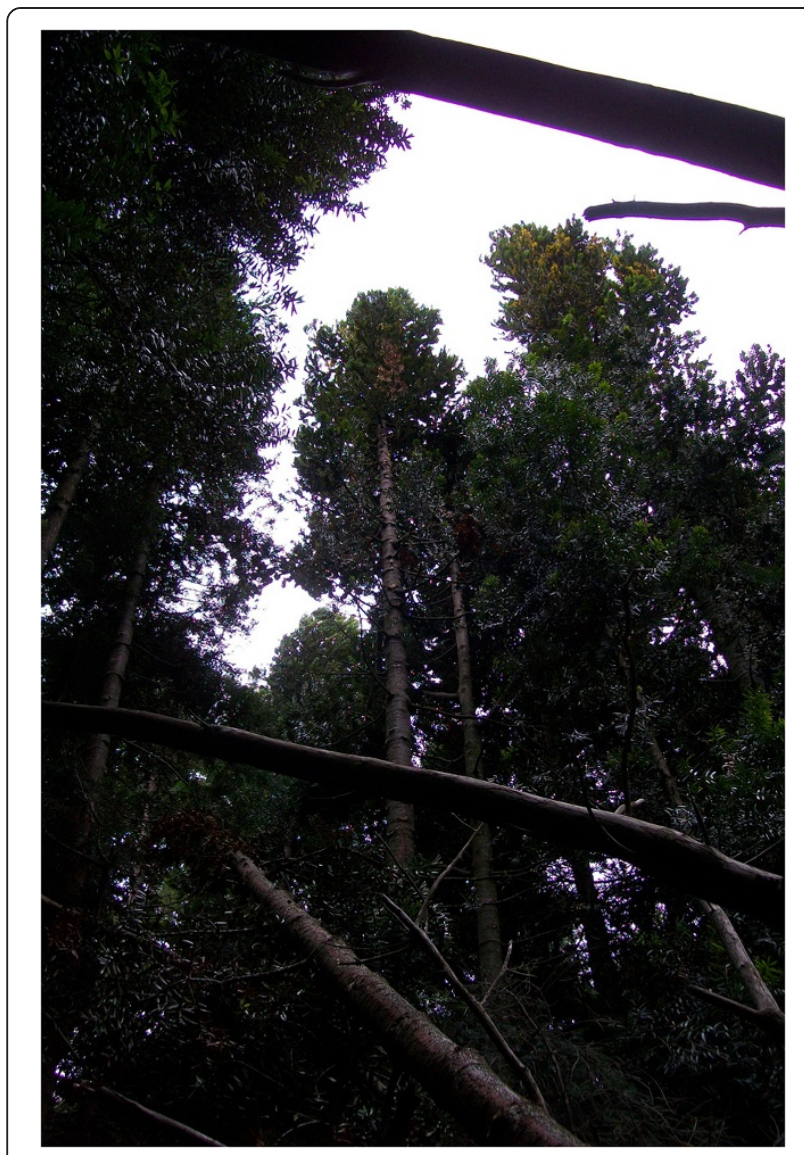

Figure 1 DK plantation mimics a natural, dense 'ricker' stand, with openings from windfall.

throughout the year but the seasonally variable temperature (CliFlo - The National Climate Database 2011) (Figure 3) with warm summers and cold winters creates large seasonal evaporation gradients. Steward (2011 pp. 43) characterises the soils as "Typic Fluvial Recent Soils (RFT) (Warepa soils derived from Schist loess over schist, greywacke and igneous rocks) of low natural fertility" using Hewitt's (1998) New Zealand classification system. The trees are growing on the relatively flat valley floor of an approximately north-south running valley. In early years after planting, the area around each tree was weeded by hand to remove competing vegetation. The surrounding forest is a mixture of planted indigenous species, generally pre-dating the kauri. The DK site generally receives $<1700$ hours of sunshine annually, compared $>1900$ hours for the majority of sites within the natural range of kauri (NIWA 2012a). The DK site is also cooler and drier than most of the natural, mainly Northland, range of kauri, which generally has mean annual temperatures $\geq 13^{\circ} \mathrm{C}$ and rainfall $\geq 1200 \mathrm{~mm}$ (NIWA 2012b).

In 1986, Pardy et al. (1992) used growth plots in planted stands of indigenous species to obtain data on the height and diameter at breast height (DBH, $1.4 \mathrm{~m}$ above ground level) growth of kauri. In later (2010, this study and Steward 2011) assessments of the performance of planted kauri, a permanent sample plot (PSP) (Ellis and Hayes 1991) was established overlying the original growth plot. The size of the PSP used was determined by the size of the stand and the number of stems per hectare. At DK, it was difficult to install a standard size sample plot (0.04 ha) (Ellis and Hayes 1997). However, adjoining plantings comprised of specimens of similar stature and similar growth rate meant that all stems within the stand were used, including those that would otherwise be defined as edge-trees (Cancino 2005). Diameter at breast height was measured for 29 trees (numbered 292 to 398, Table 1) within the plot, initially by Pardy et al. (1992) in 1986 and then again for this study in 2010. A subsample of trees (9 in 1986 and 5 in 2010) was also measured for height using a digital hypsometer Vertex fitted with a transponder (Table 1).

The DBH data collected in 2010 (this study; Steward 2011) were used to calculate the quadratic mean DBH for the stand (Table 2) using Equation 1, as the quadratic mean $\mathrm{DBH}$ is considered a more accurate representation than the arithmetic mean when estimating stand volume (Curtis and Marshall 2000).

$$
\text { Quadraticmean } D B H=\sqrt{\frac{\sum_{i=1}^{n} D B H_{i}^{2}}{n}}
$$

A curve of height against DBH was plotted and a nonlinear regression curve was fitted to the data. The regression equation was used to estimate total tree height of those stems measured for DBH but not height. Data from 48 stands of plantation and second growth kauri across New Zealand, where full site occupancy was assumed, were combined and a linear regression equation was fitted to assess the relationship between mean stand diameter and stand density. The relationship was strong $\left.R^{2}=0.88\right)$ for both planted and natural stands of kauri in a combined data set. This relationship indicates the point at which mean stand $\mathrm{DBH}$ and basal area increment slows, and where self-thinning is likely to occur unless thinning was undertaken.

$$
\text { Quadratic Mean DBH }=660.69 \times \mathrm{SD}^{-0.456} ;
$$

Steward's (2011) model is applied here in preference to Ogden and Stewart's (1995) model, as it incorporates recent and extensive measurements of plantation trees.

Mean top height and mean top diameter were calculated as the average height and quadratic mean diameter respectively of the 100 largest-DBH stems per hectare based on the height-DBH relationship established by Steward 


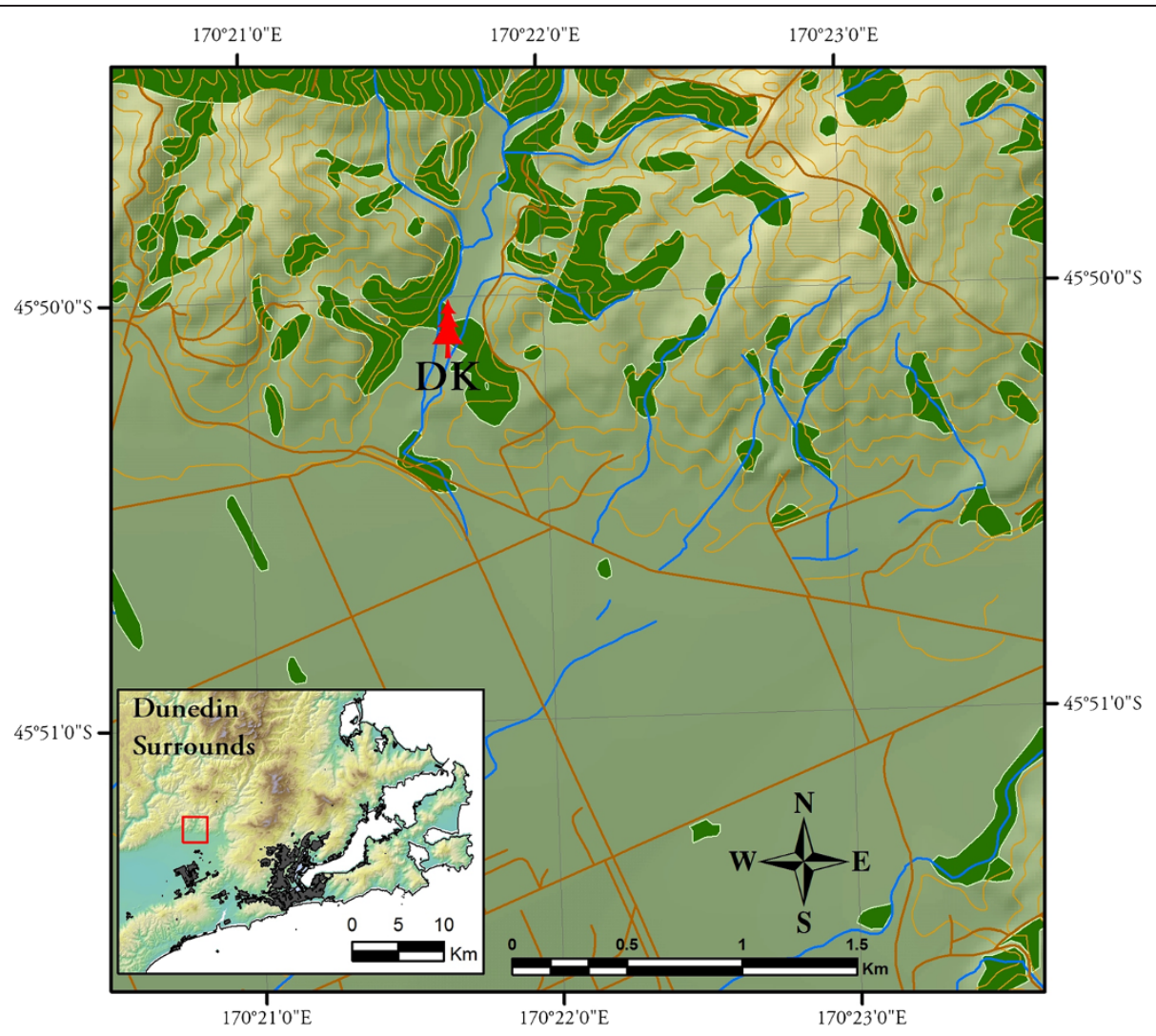

Figure 2 Site map of Wairongoa Springs (DK) on the north-eastern margin of the Taieri Plain, just west of Dunedin (inset) in New Zealand's South Island.

(2011). Basal area was calculated as the sum per hectare of cross-sectional stem area at breast height (Table 2).

Increment cores were taken over the course of two fieldtrips (2009 and 2011, separate to the 2010 sample plot measurements) without regard to the PSP due to different sampling criteria (see below). Cores were taken from bark to pith, at breast height, with a $5 \mathrm{~mm}$ increment borer at a slight upward angle. In addition to general

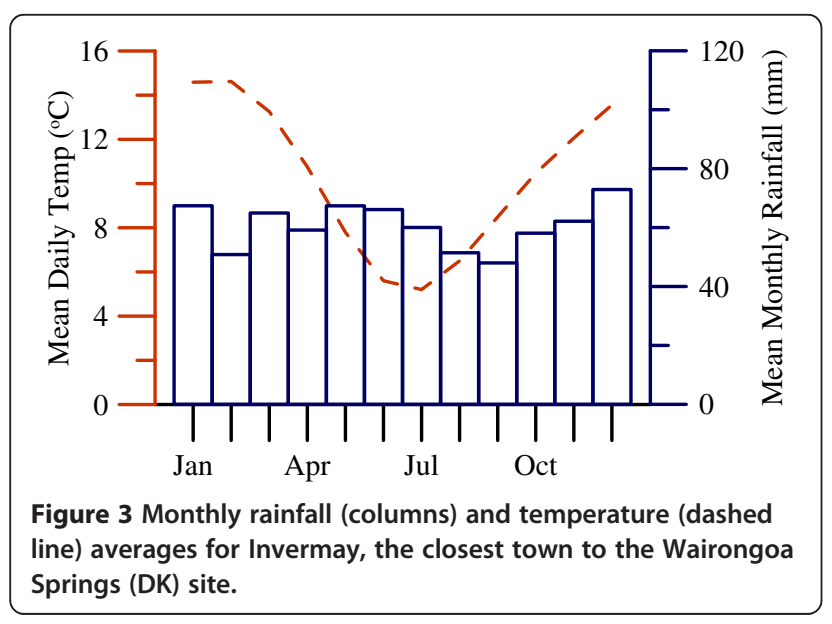

coring 'good practice' (Norton 1998), strict biosecurity controls were observed in order to guard against the transmission of the spread of diseases, particularly the pathogen Phytopthora taxon Agathis (PTA) (Waipara et al. 2013), responsible for kauri dieback in the North Island. Thirteen trees (labelled DK01 - DK13) were sampled, with 3 cores taken from DK02-DK13. Two cores were initially collected from DK01 but one was damaged during transport. (Table 3). Cores were taken $>90^{\circ}$ apart, where practical, in order to achieve maximum circumferential coverage of each tree. The mean DBH and growth rate for trees sampled for dendrochronological purposes are not an accurate reflection of the entire stand as larger trees were preferred for ring-width study. $\mathrm{DBH}$ and growth rates based on ring-width are not directly comparable as $\mathrm{DBH}$ is measured by a tape encircling a tree including the bark, while ring-width measurements are based on annual growth rings under the bark. Trees with a clear bole at breast height and a single main stem rather than a double leader were preferred, as an uninterrupted bole generally provides more easily cross-dateable cores (see below).

Cores were air dried while loosely mounted in core mounts with multiple strips of low-stick painter's tape to 
Table 1 Characteristics of 29 individual planted kauri trees at the DK site measured between 1986 (Pardy et al. 1992) and 2010 (this study)

\begin{tabular}{|c|c|c|c|c|}
\hline \multirow[t]{3}{*}{ Tree no. } & \multicolumn{4}{|c|}{ Characteristic } \\
\hline & \multicolumn{2}{|c|}{$\mathrm{DBH}(\mathrm{cm})$} & \multicolumn{2}{|c|}{ Height (m) } \\
\hline & $\begin{array}{l}1986 \text { (Pardy } \\
\text { et al. 1992) }\end{array}$ & $\begin{array}{l}2010 \\
\text { (current } \\
\text { study) }\end{array}$ & $\begin{array}{l}1986 \text { (Pardy } \\
\text { et al. 1992) }\end{array}$ & $\begin{array}{l}2010 \\
\text { (current } \\
\text { study) } \\
\end{array}$ \\
\hline 292 & 21.8 & 36.5 & 13.7 & \\
\hline 295 & 11.3 & 16.9 & & 10.2 \\
\hline 296 & 24.4 & 37 & 15.2 & \\
\hline 297 & 15.0 & 18.8 & & \\
\hline 298 & 19.7 & 32.6 & 11.6 & 19.9 \\
\hline 303 & 15.7 & 20.1 & & \\
\hline 304 & 15.9 & 23.5 & & \\
\hline 305 & 19.8 & 32.8 & 14.3 & 20.5 \\
\hline 306 & 12.8 & 17.4 & & \\
\hline 307 & 19.3 & 31.9 & 11.7 & \\
\hline 308 & 16.6 & 25.6 & 10.7 & \\
\hline 309 & 16.5 & 25.4 & & 21.1 \\
\hline 310 & 21.9 & 36.6 & 14 & \\
\hline 311 & 16.6 & 26.9 & & \\
\hline 312 & 16.8 & 28.1 & & 17.1 \\
\hline 313 & 24.8 & 38.2 & & \\
\hline 314 & 21.5 & 36.2 & 12.8 & \\
\hline 315 & 17.6 & 29.3 & & \\
\hline 316 & 17.5 & 28.8 & & \\
\hline 317 & 20.9 & 34.3 & & \\
\hline 318 & 18.5 & 30.7 & 12.5 & \\
\hline 320 & 21.2 & 36.1 & & \\
\hline 321 & 20.2 & 32.9 & & \\
\hline 322 & 19.4 & 32.3 & & \\
\hline 324 & 20.9 & 35.4 & & \\
\hline 325 & 23.8 & 36.6 & & \\
\hline 326 & 18.8 & 31.5 & & \\
\hline 327 & 20.2 & 33.1 & & \\
\hline 328 & 15.7 & 24.7 & & \\
\hline Arithmetic mean: & 18.8 & 30.0 & 12.9 & 17.8 \\
\hline Quad DBH ${ }^{1}$ & 19.1 & 30.6 & & \\
\hline Mean top height & & & 14.9 & 23.8 \\
\hline
\end{tabular}

'QQuad DBH' refers to the Quadratic Mean Diameter at Breast Height.

allow sanding to provide a 'readable' surface. Normally cores would be glued in place before sanding but the subsequent use of these cores for destructive stable isotope sampling meant non-permanent mounting was preferable. Sanded cores were visually cross-dated, using a binocular microscope when necessary. Ring-width measurements were taken using a Velmex measuring stage with a precision of $0.001 \mathrm{~mm}$. These ring-width data were then converted to a growth index (a process called standardisation). This process compares the width of an individual ring to those rings around it, making it an internally relative standard. Standardisation allowed for the comparison of fast- and slow-growing individuals on the same scale and removed trends related to age or stand dynamics. Growth-index data were then used to confirm the visual cross-dating using COFECHA software (Holmes 1983). A raw ring-width 'site master chronology' was compiled from the average of all cores.

Carbon-isotope determinations were made on annual rings dated from 1983-2009 (sliced from 18 cores from 7 trees, using a razor blade) as a pilot investigation to determine the potential for further studies (see Brookman 2014). The rings were processed to $\alpha$-cellulose using the Brendel method (Brendel et al. 2000) modified for small samples (Evans and Schrag 2004) and specifically for kauri, which appears to require more intensive extraction techniques than other resinous conifers (Brookman and Whittaker 2012). Brookman (2014) further identifies potential complications for $\delta^{13} \mathrm{C}$ extraction using the SBrendel method, which may result in small inter-annual discrepancies between real and measured values. Alphacellulose samples $(\sim 250 \mu \mathrm{g})$ were analysed using continuous flow low-temperature pyrolysis in the Stable Isotope Facility at the Department of Geological Sciences University of Canterbury, New Zealand. The mean external precision (i.e. reproducibility) of the system (Costech 4010 ECS coupled with Delta V Plus Isotope Ratio Mass Spectrometer via a ConFlo II) was greater than $0.10 \%$ for carbon, based on over 1500 measurements of reference $\alpha$-cellulose materials (Sigma-Aldrich (C8002, batch \#078K0027) and IAEA CH-3 from the International Atomic Energy Authority). All data were corrected to the Vienna Pee Dee Belemnite (V-PDB) international scale for $\delta^{13} \mathrm{C}$ using a 1-point normalisation (i.e. an additive correction) based on the Sigma Aldrich $\left(\delta^{13} \mathrm{C}:-25.44 \%\right)$ and IAEA $\mathrm{CH}-3\left(\delta^{13} \mathrm{C}:-24.724 \%\right)$ reference materials analysed in each sequence.

The quality of the DK ring-width and isotope chronologies were tested using the expressed population signal (EPS) (Briffa and Jones 1990), which essentially measures the level of common ring-width/isotope variation between trees. For the carbon isotope chronology, EPS was conducted after correction for post-industrial changes in atmospheric $\mathrm{CO}_{2}$ (McCarroll and Loader 2004), which result in a gradual decline in $\delta^{13} \mathrm{C}$. Traditionally an EPS score of 0.85 on a scale of 0 to 1 has been used as the benchmark for chronology quality. This number indicates that the record is providing 85\% 'signal' and 15\% 'noise'. Samples of kauri wood tend to show similar ringwidth signals, often achieving an EPS of 0.85 from 10 
Table 2 Stand characteristics of the planted kauri at the DK site in 2009, compared with equivalent data for all plantations and natural stands (North Island) surveyed by Steward (2011)

\begin{tabular}{llllll}
\hline Stand & \multicolumn{4}{c}{ Characteristic } \\
\cline { 2 - 6 } & Age (Years) & Mean top height $(\mathbf{m})^{\mathbf{1}}$ & Quad DBH $^{\mathbf{2}}$ & Quad MAl $^{\mathbf{3}}$ & Stems ha $^{\mathbf{1}}$ \\
\hline DK only & 55 & 23.8 & 30.6 & 0.56 & 875 \\
All stands & 54 & 20.0 & 33.1 & 0.63 & 804 \\
\hline
\end{tabular}

${ }^{1}$ Mean Top DBH to the modelled DBH expected when kauri reach the theoretical 'top height' (i.e. felling age/proportion in a forestry sense) at age 50.

${ }^{2 \prime}$ Quad DBH' refers to the Quadratic Mean Diameter at Breast Height.

${ }^{3}$ Quad MAI refers to 'Quadratic Mean Annual Increment (ie. growth)'.

trees (Fowler and Boswijk 2003) whereas other species may require up to 25 samples (Briffa and Jones 1990). The EPS was calculated using the 'detrendeR' (Campelo et al. 2012) package in ' $R$ ' (R-Core-Team 2012) in overlapping 10-year windows as well as the entire length of the ring-width chronology, while the carbon isotope record was analysed only as a single time period due to its shorter duration. The site ring-width master record was analysed for growth-trend changes using the segmented regression freeware SegReg (Oosterbaan n.d; Oosterbaan et al. 1990).

\section{Results and discussion}

\section{Sample plot growth results}

Based on the average quadratic mean DBH of $30.6 \mathrm{~cm}$ in the 55-year-old trees (at time of measurement), the average annual growth for the DK stand is $\sim 5.6 \mathrm{~mm} \mathrm{year}^{-1}$. The DBH of individual trees ranged from 16.9 to $38.2 \mathrm{~cm}$. Measured tree heights ranged from 10.2 to $21.1 \mathrm{~m}$, with a mean of $17.8 \mathrm{~m}$. Based on height-DBH relationship calculated, this established a mean top height for the stand of $23.8 \mathrm{~m}$. In comparison, the trees surveyed by Pardy et al. (1992) in 1986 ranged from 11.3 to $24.8 \mathrm{~cm}$ $\mathrm{DBH}$, with a quadratic mean $\mathrm{DBH}$ of $19.1 \mathrm{~cm}$, suggesting an average annual growth of $\sim 6.2 \mathrm{~mm} \mathrm{year}^{-1}$. Trees measured by Pardy et al. (1992) ranged from 10.7 to $15.2 \mathrm{~m}$ tall, with a mean top height of $14.9 \mathrm{~m}$.

The $5.6 \mathrm{~mm}_{\text {year }}{ }^{-1} \mathrm{DBH}$ growth established from trees within the growth plot shows that the DK trees are growing more rapidly than most young naturally occurring stands. Pardy et al. (1992) suggested that, in the early 'pole' stages of growth, it is not uncommon for $5 \mathrm{~mm}$ annual diameter increases in naturally occurring stands, which is in good agreement with the figure of $4.3 \mathrm{~mm}_{\text {year }}{ }^{-1}$ reported by Burns and Smale (1990) from 1 to 200-year-old trees, generally still in 'ricker' form, on the Coromandel Peninsula. Steward and Kimberley (2002) recorded somewhat slower growth $\left(1.3-3.4 \mathrm{~mm} \mathrm{year}^{-1}\right)$ in another natural stand of trees 120-218 years old. Considering climate alone, the higher average growth-rate of DK trees compared to naturally occurring stands further north is worthy of comment. However, the site selection and silvicultural attention afforded plantation trees introduce a number of variables beyond climate. It is not unusual for plantations of many species, even beyond their naturally occurring range, to exceed natural growth rates (Pardy et al. 1992). A large part of the success of kauri at DK is likely due to site selection: growth trials have shown that kauri grow best amongst gaps within taller surrounding vegetation (I Barton, personal communication). It may be that the surrounding, established plantation of indigenous species at DK generated a favourable microclimate for kauri growth. Surrounding forest cover may help explain why Bergin and Steward (2004) suggested that there is no evidence of frost damage to DK trees, despite the fact that the area would regularly receive frosts lower than -4 to $-6^{\circ} \mathrm{C}$, which Barton $(1982,1985)$ found caused lasting damage or death of kauri seedlings. Frost damage may be a primary cause of multiple leaders in kauri, which are very rare on naturally established trees in forest or scrub-land (I Barton personal communication). There are multiple trees at DK with double-leaders which could suggest some, non-fatal frost damage to seedlings rather than no frost damage as reported by Bergin and Steward (2004).

Perhaps a fairer growth comparison is between DK trees and that of other surveyed kauri plantations, all of which are in the North Island. Plantation kauri generally grow faster than naturally occurring stands and, in some cases, trees have averaged $10 \mathrm{~mm}$ (diameter) growth for up to 40 years (Steward and Beveridge 2010). The estimated mean annual growth rate of the DK stand, based on external $\mathrm{DBH}$ measurement of a quadrat selected without size bias, $\left(5.6 \mathrm{~mm} \mathrm{year}^{-1}\right)$ is only $0.7 \mathrm{~mm}_{\text {year }}{ }^{-1}$ slower than the mean of 25 stands of planted kauri surveyed by Steward (2011) (Table 2). It is also comparable to the $6.9 \mathrm{~mm}$ year $^{-1}$ average measured by Pardy et al. in 1986 (Pardy et al. 1992) if the early growth of DK is used. Ring-width data prior to 1983 (see below) suggests that DK trees grew $\sim 12 \%$ faster than their longterm mean, meaning that mean growth was likely closer to $6.3 \mathrm{~mm}$ year $^{-1}$ at the time of the Pardy et al. sampling in 1986 (Pardy et al. 1992).

The height growth of the DK trees has exceeded the average seen in 25 planted stands within and outside the current natural range of the species (Table 2). Models of height growth of kauri in planted stands have been produced in an on-going study of the potential productivity 
Table 3 Summary of the dendrochronological record for 13 kauri trees at the DK site detailing the years covered by each core and the correlation of each core with the site master record, along with DBH measured in 2011

\begin{tabular}{|c|c|c|c|c|}
\hline $\begin{array}{l}\text { Tree } \\
\text { code }^{1}\end{array}$ & $\begin{array}{c}\text { Core } \\
\text { number }\end{array}$ & $\begin{array}{l}\text { DBH } \\
(\mathrm{cm}) \\
\end{array}$ & $\begin{array}{l}\text { Record } \\
\text { period }\end{array}$ & $\begin{array}{l}\text { Correlation with master } \\
\text { record }(1980-2009)^{2}\end{array}$ \\
\hline DK01 & 1 & 37.0 & $1962-2008$ & $0.42 \mathrm{~A}$ \\
\hline \multirow[t]{3}{*}{ DKO2 } & 1 & 32.7 & $1961-2008$ & 0.55 \\
\hline & 2 & & $1970-2008$ & 0.57 \\
\hline & 3 & & $1961-2009$ & 0.54 \\
\hline \multirow[t]{3}{*}{ DK03 } & 1 & 39.7 & $1964-2008$ & 0.51 \\
\hline & 2 & & $1970-2008$ & 0.61 \\
\hline & 3 & & 1963-2009 & 0.77 \\
\hline \multirow[t]{3}{*}{ DK04 } & 1 & 32.5 & $1974-2008$ & 0.63 \\
\hline & 2 & & $1964-2008$ & 0.45 \\
\hline & 3 & & 1963-2009 & 0.50 \\
\hline \multirow[t]{3}{*}{ DK05 } & 1 & 32.5 & $1967-2008$ & 0.64 \\
\hline & 2 & & $1957-2008$ & 0.55 \\
\hline & 3 & & $1957-2009$ & $0.33 \mathrm{~A}$ \\
\hline \multirow[t]{3}{*}{ DK06 } & 1 & 33.7 & $1967-2009$ & $0.35 \mathrm{~A}$ \\
\hline & 2 & & 1971-2009 & 0.69 \\
\hline & 3 & & 1960-2009 & 0.65 \\
\hline \multirow[t]{3}{*}{ DK07 } & 1 & 36.9 & 1963-2009 & 0.51 \\
\hline & 2 & & 1968-2009 & 0.55 \\
\hline & 3 & & 1963-2009 & 0.65 \\
\hline \multirow[t]{3}{*}{ DK08 } & 1 & 37.5 & 1966-2009 & 0.70 \\
\hline & 2 & & 1964-2009 & $0.31 \mathrm{~B}$ \\
\hline & 3 & & 1964-2009 & 0.66 \\
\hline \multirow[t]{3}{*}{ DK09 } & 1 & 28.6 & $1965-2009$ & $0.29 B$ \\
\hline & 2 & & 1969-2009 & $0.33 \mathrm{~A}$ \\
\hline & 3 & & 1959-2009 & 0.54 \\
\hline \multirow[t]{3}{*}{ DK10 } & 1 & 33.0 & $1962-2009$ & 0.71 \\
\hline & 2 & & $1967-2009$ & 0.54 \\
\hline & 3 & & $1967-2009$ & 0.62 \\
\hline \multirow[t]{3}{*}{ DK11 } & 1 & 33.0 & $1962-2009$ & 0.63 \\
\hline & 2 & & $1963-2009$ & 0.50 \\
\hline & 3 & & 1964-2009 & 0.67 \\
\hline \multirow[t]{3}{*}{ DK12 } & 1 & 32.4 & 1969-2009 & 0.70 \\
\hline & 2 & & $1972-2009$ & 0.52 \\
\hline & 3 & & 1963-2009 & 0.69 \\
\hline \multirow[t]{5}{*}{ DK13 } & 1 & 31.5 & $1962-2009$ & 0.57 \\
\hline & 2 & & $1962-2009$ & 0.70 \\
\hline & 3 & & 1967-2009 & 0.87 \\
\hline & Range/Mean: & 33.9 & 1957-2009 & 0.57 \\
\hline & & & 45.1 & \\
\hline
\end{tabular}

${ }^{1}$ One core from DK01 was damaged during transport and consequently excluded from analysis.

${ }^{2}$ Cores not reaching the 0.42 (99\%) correlation threshold are marked A (under $99 \%$ significance level but highest as dated) or B (correlation higher at other than dated position) of kauri (Bergin and Steward 2004; Chikumbo and Steward 2007; Steward and Beveridge 2010; Steward and McKinley 2005). Height growth is frequently used in forestry to determine a 'site index', which refers to the timber potential for a site, usually at a fixed age somewhere near the expected rotation length for the species. For kauri in planted stands, site index was defined by Steward (2011) as Mean Top Height at age 50. The site Index for DK was $22.7 \mathrm{~m}$, against a national average of $20.4 \mathrm{~m}$ (Steward 2011). A comparison of predicted height growth from five individual planted stands (Figure 4, using data from Steward 2011) located from Whangarei to the Bay of Plenty with the DK stand shows that, despite their southern location, height growth for DK trees is similar to that for plantations within or near the modern natural range of the species.

\section{Ring-width and isotope chronology quality}

The dendrochronological investigation of the DK kauri proved challenging due to a lack of distinct marker rings in the relatively brief (52-year) chronology. Six (of 37) cores failed to meet the $99 \%$ significance correlation level usually used to determine successful cross-dating. This could be the result of a number of factors, including:

1) Age: plantation kauri grow quickly when young (40-60 years) before growth slows once trees pass the 'ricker' phase. This period of accelerated growth may obscure climatic signals and often coincides with high attrition rates as young trees compete for limited resources. Attrition within the stand often introduces micro-scale, non-climate variability to the ring-width record, lowering the coherent signal within the stand (Wunder et al. 2013).

2) Microclimate: the DK kauri grow on a flat site in a sheltered environment, at the northern end of the Taieri Plain, that is subject to less severe weather than much of the surrounding region. It may be that the trees are subject to few growth-limiting/stressful conditions, creating a 'complacent' chronology.

While some researchers 'improve' their chronology results by removing data for poorly correlated cores (e.g. Fowler and Boswijk 2003), all available data is included here. Results from EPS for the DK site suggest that the common signal between trees is strong despite those cores that presented problems in cross-dating. The early section of the chronology, before all trees/cores are represented, is the only stage where EPS values are below 0.85. From 1967 onwards, 10-year windows of ring-width data (overlapped by 5 years) show EPS $>0.85$ (Table 4). These results suggest that tree growth was related to environmental conditions. 


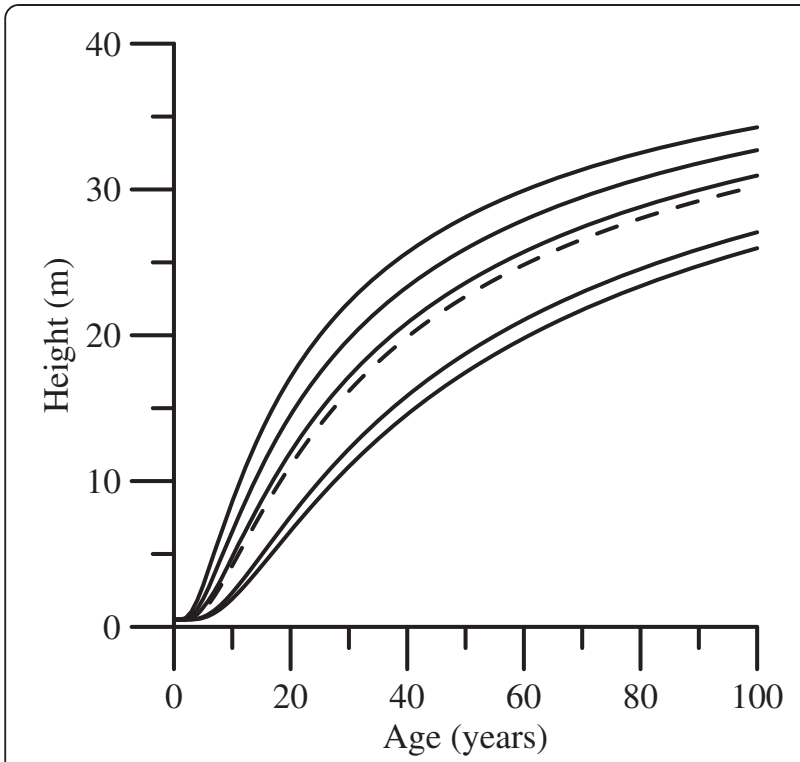

Figure 4 Predicted height growth of DK kauri compared to North Island plantations. Model of predicted height growth of kauri planted at Wairongoa Springs (DK) (dashed line) and kauri in planted stands from Whangarei to the Bay of Plenty (adapted from Steward 2011).

The EPS result for carbon isotope site chronology $(0.68)$ is much lower than that for ring-width $\sim 0.85$. A major factor here is likely to be the disparity in sampledepth between the ring-width record (37 cores) and the isotope record (18 cores), which was a preliminary study. Even so, the EPS obtained here is low compared to results for different species from other isotope studies in which 4-6 trees have often been sufficient to produce EPS scores $>0.85$ (e.g. Robertson 1997a, b; McCarroll and Pawellek 2001; Porter et al. 2009). The most likely reason for this is considered to be a combination of the sensitivity of young trees to micro-scale endogenous influences

Table 4 Expressed population signal scores for 10-year periods in of the chronology of 13 kauri trees at DK

\begin{tabular}{lllll}
\hline Start year & End year & No. trees & No. cores & EPS score \\
\hline 1962 & 1971 & 8 & 11 & 0.158 \\
1967 & 1976 & 13 & 29 & 0.867 \\
1972 & 1981 & 13 & 36 & 0.953 \\
1977 & 1986 & 13 & 37 & 0.940 \\
1982 & 1991 & 13 & 37 & 0.932 \\
1987 & 1996 & 13 & 37 & 0.970 \\
1992 & 2001 & 13 & 37 & 0.940 \\
1997 & 2006 & 13 & 37 & 0.924 \\
$1974^{1}$ & 2008 & 13 & 37 & 0.959 \\
\hline
\end{tabular}

${ }^{1}$ The 'common interval' EPS, which represents the overall EPS for the time period covered by all individual cores. and the difficulties of processing kauri wood to $\alpha$-cellulose (Brookman and Whittaker 2012; Brookman 2014).

\section{Interpreting ring-width growth patterns}

The average ring-width was $3.10 \mathrm{~mm}$ for the period studied, which translates to a DBH increase of $\sim 6.2 \mathrm{~mm} \mathrm{year}^{-1}$ although ring-width decreased with increasing age (Figure 5A). When analysed using segmented linear regression, however, tree growth can be split into two phases centred on a 'break-point' of 1983 ( \pm 5.6 years, 95\% confidence interval). The early phase from 1957 to 1983 showed a constant (slope $<0.01, r^{2}=0.01$ ) mean ring-width $\left(3.5 \mathrm{~mm} \mathrm{year}^{-1}\right)$. From 1983 onward, there was a steady and significant $\left(0.06 \mathrm{~mm} \mathrm{yr}^{-1}, r^{2}=\right.$ $0.71, p<0.05$ ) decrease in ring-width (Figure $5 \mathrm{~B}$ ). This segmented linear regression model provides an 'explained coefficient' of 0.61 , showing the improved fit of the model compared to a 'whole record' linear regression $\left(r^{2}=0.47\right)$.

The early growth spurt, followed by a decline in growth-rate, fits patterns observed in other indigenous tree plantations with minimal silvicultural management (Pardy et al. 1992). The growth-rate models developed for kauri by Steward (2011) provide an explanation for the growth-rate decline documented in the ring-width record. Generally, the most likely cause of growth-rate decline is resource competition/limitation. At DK, trees were densely planted by forestry standards $(\sim 1250$ stems $\mathrm{ha}^{-1}$ ) in a small plot surrounded by established plantings (Steward 2011). While this is many times denser than estimated natural densities of 50-200 stems ha ${ }^{-1}$ for mature forest (Ahmed and Ogden 1987), it is comparable to the densities observed by Barton (1982) in the 'subdominant' and 'shrub' strata of natural stands. Plantation density itself does not necessarily limit growth but experiments showed that nutrient availability has a profound effect on growth (Barton and Madgwick 1987). Nutrient and root space competition as well as limited light access in a rapidly converging canopy often result in growth-rate decline, with weaker individuals dying when their leaves no longer receive enough light to maintain positive carbon balance. The magnitude of this 'self thinning' effect is much debated in general forestry literature but the general principle is well established (Sackville-Hamilton et al. 1995). For kauri, the general hypothesis of self-thinning is supported by the observations of self-thinning made by Steward (2011) from plantation trees and Burns and Smale (1990) in secondgrowth natural stands.

At the last measurement (March 2010), the DK stand had a quadratic mean diameter of $30.6 \mathrm{~cm}$, at a stand density of 875 stems ha ${ }^{-1}$ (Table 2). At 875 stems ha $^{-1}$, the model for self-thinning predicts a diameter of $30.1 \mathrm{~cm}$ as the point where radial growth-rate will decline and natural 

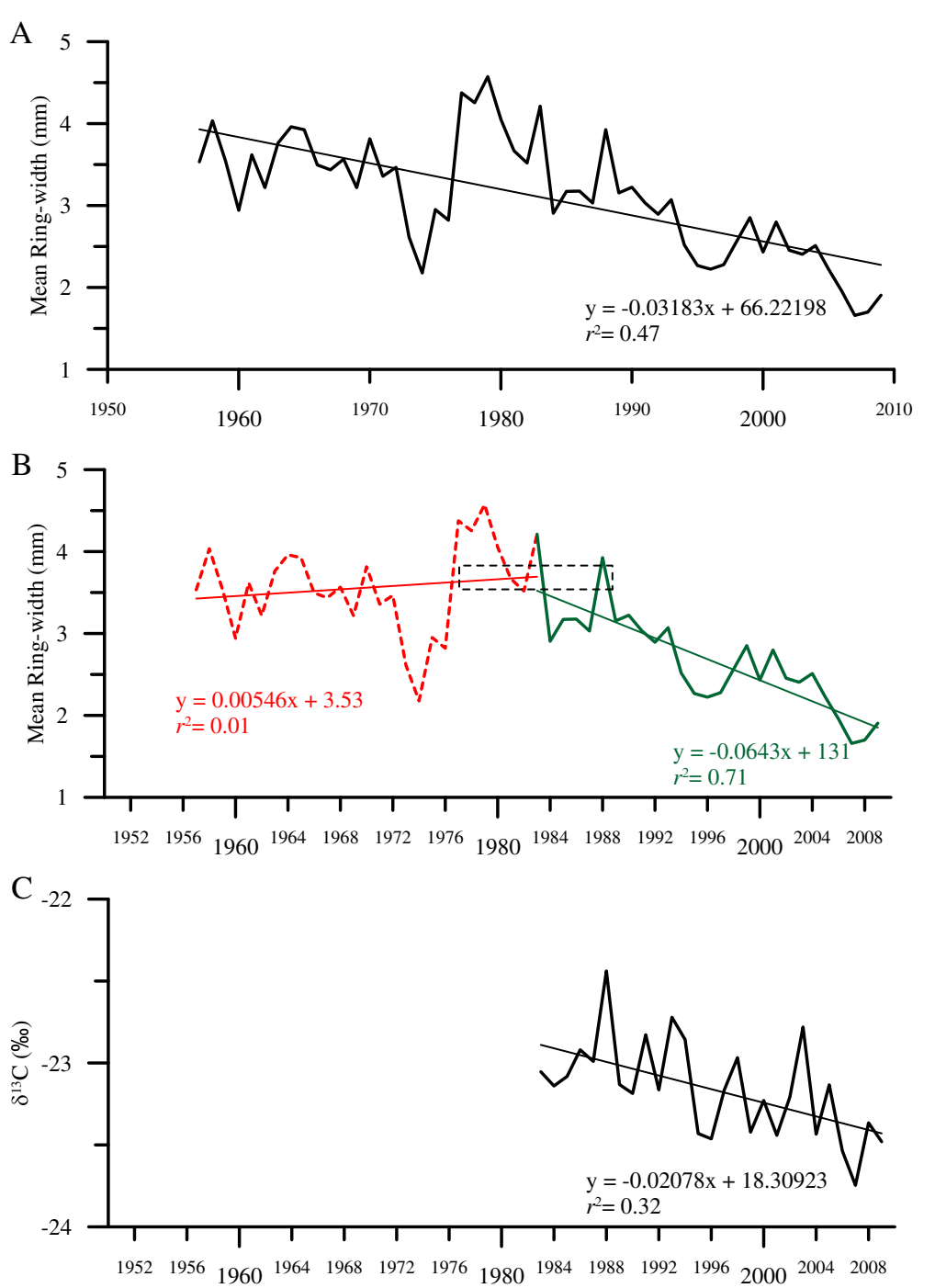

Figure 5 Master ring-width and carbon isotope time-series for DK. A) The mean, raw ring-width chronology, showing a gradual decrease in annual growth over the 52-year record. B) The same chronology broken into two portions using segmented regression, showing 26 years of relatively constant growth followed by a growth-rate decline after 1983 (Black, dashed box indicates 95\% Cl of 1983 break-point). C) The separately determined carbon isotope record, showing the gradual decline in $\delta^{13} \mathrm{C}$ from 1983-2009/11.

mortality becomes likely to occur if thinning is not undertaken. As the DBH of trees in the DK stand only recently ( 2009) exceeded the predicted DBH, it may be some time before actual mortality occurs. In other densely stocked kauri stands that are close to or have exceeded the selfthinning line, self-shading within the stand results and the lower crown collapses. Initially height growth may replace diameter growth as individual trees compete for growing space and dominance. Artificial thinning of kauri in planted stands at New Plymouth resulted in a delay of onetwo years before crown replacement and a rapid return to diameter growth. Similarly, results from thinned natural stands indicate that trees in a dense natural stand endured a long period of suppressed growth (Madgwick et al. 1982) before rapid diameter growth post-thinning (Barton and Madgwick 1987).

The DK ring-width record suggests that the onset of self-thinning may have preceded the density-modelled timing (2009) by $26 \pm 5.6$ years based on the 1983 breakpoint evident in the segmented regression. It is important to note that the 2009 and 1983 dates are only approximately comparable as the former is based on an 'over-bark' measure of DBH while the latter excludes bark. The suggested early onset of self-thinning may serve to explain why the DK trees exceed the plantation height average, as they have prioritised height growth over diameter growth in an extended competition for light. The earlier onset of light-based competition at DK 
compared to observations from other kauri stands could be explained by the other, more mature mixed plantings of indigenous trees surrounding the DK site shading the kauri and creating an enhanced level of light competition. The shorter growing season and reduced sunshine hours at the DK site compared to climates in the natural range of kauri may also contribute.

\section{Interpreting the carbon isotope record}

Further support for the early onset of self-thinning due to competition for sunlight is provided by the carbon isotope record compiled from DK trees. Across the 1983-2009 period, there is a significant $(p<0.05)$ decreasing trend in $\delta^{13} \mathrm{C}$ (Figure $5 \mathrm{C}$ ) despite correction for the trend of post-industrial atmospheric $\mathrm{CO}_{2}$ depletion. The direction of the trend in $\delta^{13} \mathrm{C}$ observed here is opposite to the positive trend generally considered characteristic of the 'juvenile effect', so it may be that this trend is not directly age related. In fact, it may be considered to exist 'in spite' of age, as the 'juvenile effect' documented for kauri lasted 200 (Jansen 1962) or more (Grinsted and Wilson 1979) years. Walcroft (1994) was the first to note a reversal of the normal juvenile pattern when he observed higher $\delta^{13} \mathrm{C}$ in juvenile kauri leaves compared to mature leaves. He suggested that the most likely cause was the morphological differences between juvenile and mature foliage; juvenile leaves have a thinner cuticle and consequently are likely to lose more water through peristomatal respiration than xerophyllic mature leaves (Walcroft 1994). The likely result is that stomatal conductance in juvenile leaves is restricted to maintain leaf-water potential, thereby decreasing the relative pressure of intercellular to ambient $\mathrm{CO}_{2}$. This change means that there is limited intercellular $\mathrm{CO}_{2}$ available for the carboxylation process (the first stage of $\mathrm{CO}_{2}$ fixation during photosynthesis), resulting in reduced fractionation and raising $\delta^{13} \mathrm{C}$ (Francey and Farquhar 1982).

While leaf morphology may contribute to the decreasing trend in $\mathrm{DK} \delta^{13} \mathrm{C}$, there may be another possible cause. One frequently postulated cause of the "juvenile effect' is the gradual decrease in the shading from the canopy as young trees grow taller (Francey and Farquhar 1982); The photosynthetic rate increases as trees receive more sunlight, lowering the relative pressure of intercellular to ambient $\mathrm{CO}_{2}$, causing $\delta^{13} \mathrm{C}$ to rise. A related hypothesis is that as trees grow they have more access to atmospheric $\mathrm{CO}_{2}$, which is enriched in ${ }^{13} \mathrm{C}$ compared to the sub-canopy $\mathrm{CO}_{2}$, which is ${ }^{13} \mathrm{C}$ depleted, having been respired by upper layers of the canopy (Schleser and Jayasekera 1985). However, in the plantation environment at DK the situation may be reversed; seedlings, planted in a clearing had little competition for light and were in a well-mixed, rather than stratified, atmosphere.
The dense plantation layout means that, as the trees have grown, competition for light has increased due to shading from adjacent canopies. Canopy shading reduces photosynthesis (Walcroft et al. 2002) and results in lower $\delta^{13} \mathrm{C}$ (Francey and Farquhar 1982), so this plantation-specific situation of increased competition with height may be chemically represented in the treering cellulose $\delta^{13} \mathrm{C}$. Unfortunately, the tree-ring data presented here cannot provide a conclusive answer to this question, as they only cover the period of decreasing ring-width. Consequently, it is not possible to assess whether tree-ring $\delta^{13} \mathrm{C}$, like ring-width, was relatively constant prior to 1983 , or whether the gradual decrease is constant throughout the life of the trees, which may suggest a gradual change in carbon isotope discrimination during photosynthesis in response to increased atmospheric $\mathrm{CO}_{2}$ concentration (Treydte et al. 2009). However, based on the data available, it is possible that this 'reverse juvenile effect' may be a chemical analogy for the decrease in ring-width over the same time period, caused by the same increased light competition. Whether leaf morphology, canopy shading, or a combination of the two are responsible for the 'reverse juvenile effect' documented, a potentially valuable avenue of inquiry for dendroclimatic study of kauri chemistry is to establish whether similar situations occur in naturally occurring kauri stands, where saplings grow into dense ricker-thickets. Such a finding would require researchers to consider disregarding multi-decadal (or longer) trends in any juvenile trees/rings. Although this cautionary approach has already been adopted by some researchers (Leavitt 2010), the relatively minor age effects associated with dendrochemistry compared with ring-width study is seen as one of its major strengths (Loader et al. 2013). While not conclusive in their own right, the preliminary results presented here raise a number of valuable questions regarding $\delta^{13} \mathrm{C}$ juvenile effects that require further study of both plantation and natural kauri.

\section{Conclusions}

The existence of planted kauri at DK provides a special opportunity to better understand the ecology and forestry potential of one of New Zealand's iconic species well outside its current natural range. Similarity in ringwidth patterns among trees at DK shows a consistent response to the environment. The average growth rate of DK trees is comparable to other plantations situated much further north, an exceptional result given that DK is $>20 \%$ cooler, $>40 \%$ drier and receives $>200$ less sunshine hours each year than most of the current natural range of kauri. A period of continuous, rapid growth occurred prior to 1983 but has consistently slowed since then, probably reflecting competition for light. This is may suggest the onset of the 'self thinning' process, well 
documented for kauri. A corresponding decrease in treering $\delta^{13} \mathrm{C}$ since 1983 could also be explained by increased light competition, creating a 'reverse juvenile effect', which serves as a dendrochemical analogy for the self-thinning evident ring-width signal. The onset of growth decline is much earlier ( $26 \pm 5.6$ years) than modelling predicts, which may reflect site specific influences related to enhanced light competition and/or climatic stress due to the reduced temperature, rainfall and sunshine hours for DK compared North Island locations. Nonetheless, the success of the DK plantation suggests that kauri can be successfully grown in sheltered sites well south of its natural range, although stand density may need to be slightly lower than northern plantations to avoid early onset self-thinning.

\section{Competing interests}

The authors declare that they have no competing interests.

\section{Authors' contributions}

THB co-designed the dendrochronological research, conducted fieldwork, processed and analysed samples for carbon isotope determination, statistically analysed data and conceived and prepared the manuscript. GAS developed and contributed the kauri forestry modelling, conducted the PSP measurements and contributed to the writing of the corresponding sections of the manuscript. JGP co-designed the dendrochronological research, conducted fieldwork and revised the manuscript. PF conducted all dendrochronology and revised the manuscript. AHB facilitated fieldwork, provided historical background to the site and revised the manuscript. TWH contributed to project design, stable isotope analysis and manuscript preparation. All authors read and approved the final manuscript.

\section{Acknowledgements}

Clare Banks and Michael Bradfield are thanked for helping facilitate the fieldwork. The manuscript benefited greatly from discussions with Andrew Lorrey and the insightful comments of Ruth Falshaw, lan Barton, and an anonymous reviewer. The cross-dating was made possible by the Royal Society of New Zealand Hutton Fund award to THB. The Mason Trust, AMP New Zealand and The Todd Foundation are also thanked for their support of the research.

\section{Author details}

'Department of Geological Sciences, University of Canterbury, Private Bag 4800, Christchurch 8140, New Zealand. ${ }^{2}$ SCION, Private Bag 3020, Rotorua 3046, New Zealand. ${ }^{3}$ Climate Change Research Centre, University of New South Wales, Wales, NSW 2052, Australia. ${ }^{4}$ Gondwana Tree-Ring Laboratory, PO Box 14, Little River, Canterbury, New Zealand. ${ }^{5}$ Wairongoa Springs, Wairongoa Road, RD 2, Mosgiel 9092, New Zealand.

Received: 20 June 2013 Accepted: 19 April 2014

Published online: 07 August 2014

\section{References}

Ahmed, M, \& Ogden, J. (1987). Population dynamics of the emergent conifer Agathis australis (D. Don) Lindl. (kauri) in New Zealand I. Population structures and tree growth rates in mature stands. New Zealand Journal of Botany, 25, 217-229.

Barton, IL. (1982). An investigation of aspects of the ecophysiology and ecology of Kauri (Agathis austrlis-Salisb). Hamilton: Master of Philosophy, University of Waikato.

Barton, IL. (1985). Winter frost and its effect on kauri (Agathis australis) seedlings. New Zealand Journal of Forestry, 30(1), 94-101.

Barton, IL, \& Madgwick, HAl. (1987). Response of a kauri stand to fertiliser addition and thinning. New Zealand Forestry, 32(2), 19-21.

Baskerville, GL. (1972). Use of logarithmic regression in the estimation of plant biomass. Canadian Journal of Forest Research, 2(1), 49-53.

Bergin, D, \& Steward, G. (2004). Kauri: Ecology, Establishment, Growth, and Management (Vol. 2, New Zealand Indigenous Tree Bulletin). Rotorua: Forest Research Institute.
Boswijk, G, Fowler, A, Lorrey, A, Palmer, J, \& Ogden, J. (2006). Extension of the New Zealand kauri (Agathis australis) chronology to 1724 BC. The Holocene, 16(2), 188-199.

Brendel, O, lannetta, PPM, \& Stewart, D. (2000). A rapid and simple method to isolate pure alpha-cellulose. Phytochemical Analysis, 11, 7-10.

Briffa, K, \& Jones, P. (1990). Basic Chronology Statistics and Assessment. In E. Cook \& L. Kairiukstis (Eds.), Methods of Dendrochronology: Applications in the Environmental Sciences (pp. 137-152). Dordrecht: Kluwer Academic.

Brookman, TH. (2014). Stable Isotope Dendroclimatology of New Zealand kauri (Agathis australis (D. Don) Lindl.) and cedar (Libocedrus bidwillii Hook. f.). Christchurch, New Zealand: PhD, University of Canterbury.

Brookman, TH, \& Whittaker, TE. (2012). Experimental assessment of the purity of a-cellulose produced by variations of the Brendel method: Implications for stable isotope $\left(\delta^{13} \mathrm{C}, \delta^{18} \mathrm{O}\right)$ dendroclimatology. Geochemistry, Geophysics, Geosystems, 13(9), doi:10.1029/2012GC004215.

Burns, B. (1999). Managing planted native stands: what can we learn from the ecology of natural forests. In W. Silvester \& R. McGowan (Eds.), Native trees for the future: potential, possibilities, problems, University of Waikato, 8-10 October 1999 (pp. 47-50). Hamilton, Waikato: University of Waikato.

Burns, B. (2009). Research on indigenous forestry. In I. Barton, R. Gadgil, \& D. Bergin (Eds.), Managing Native Trees: Towards a National Strategy, University of Waikato, 18-20 November 2009 (pp. 110-112). Pukekohe: Tāne's Tree Trust.

Burns, BR, \& Smale, MC. (1990). Changes in structure and composition over fifteen years in a secondary kauri (Agathis australis)-tanekaha (Phyllocladus trichomanoides) forest stand, Coromandel Peninsula, New Zealand. New Zealand Journal of Botany, 28, 141-158

Campelo, F, García-González, I, \& Nabais, C. (2012). detrendeR - a graphical user interface to process and visualize tree-ring data using R. Dendrochronologia, 30, 57-60.

Cancino, J. (2005). Modelling the edge effect in even-aged Monterey pine (Pinus radiata D. Don) stands. Forest Ecology and Management, 210(1-3), 159-172.

Chikumbo, O, \& Steward, GA. (2007). A stand basal area model for plantation grown New Zealand kauri. Ecological Modelling, 209, 367-376.

Cliflo - The National Climate Database. (2011). NIWA. http://cliflo.niwa.co.nz/.

Curtis, RO, \& Marshall, DD. (2000). Why quadratic mean diameter? Western Journal of Applied Forestry, 15(3), 137-139.

Ecroyd, CE. (1982). Biological flora of New Zealand: 8. Agathis australis (D. Don) Lindl.* (Araucariaceae) kauri. New Zealand Journal of Botany, 20, 17-36.

Ellis, JC, \& Hayes, JD. (1991). Minimum standards for collection of growth data from Permanent Sample Plots (Report No. 4 of Stand Growth Modelling Cooperative).

Ellis, JC, \& Hayes, JD. (1997). Field Guide for Sample Plots in New Zealand Forests. (FRI Bulletin Vol. 186). Rotorua: New Zealand Forest Research Limited.

Evans, WP. (1937). Note on the flora which yielded the Tertiary lignites of Canterbury, Otago and Southland. New Zealand Journal of Science and Technology, 15, 365-385.

Evans, MN, \& Schrag, DP. (2004). A stable isotope-based approach to tropical dendroclimatology. Geochimica et Cosmochimica Acta, 68(16), 3295-3305.

Farquhar, GD, \& Richards, RA. (1984). Isotopic composition of plant carbon correlates with water-use efficiency of wheat genotypes. Australian Journal of Plant Physiology, 11, 539-552.

Farquhar, GD, O'Leary, MH, \& Berry, JA. (1982). On the relationship between carbon isotope discrimination and intercellular carbon dioxide concentration in leaves. Australian Journal of Plant Physiology, 9, 121-137.

Farquhar, GD, Ehleringer, JR, \& Hubick, KT. (1989). Carbon isotope discrimination and photosynthesis. Annual Review of Plant Physiology, 40, 503-537.

Fowler, A, \& Boswijk, G. (2003). Chronology stripping as a tool for enhancing the statistical quality of tree-ring chronologies. Tree-Ring Research, 59(2), 53-62.

Francey, RJ, \& Farquhar, GD. (1982). An explanation of ${ }^{13} \mathrm{C}^{12} \mathrm{C}$ variations in tree rings. Nature, 297, 28-31.

Fritts, HC. (1976). Tree rings and climate. London: Academic Press.

Grinsted, MJ, \& Wilson, AT. (1979). Variations of ${ }^{13} \mathrm{C} /{ }^{12} \mathrm{C}$ ratio in cellulose of Agathis australis (kauri) and climatic change in New Zealand during the last millenium. New Zealand Journal of Science, 22, 55-61.

Herbert, J, Glass, B, \& Kimberley, M. (1996). A preliminary stand productivity and economic case study of plantation growth kauri. In An alternative approach to forestry - time to review! Proceedings of the New Zealand Institute of Forestry, Invercargill, New Zealand, 29 April - 1 May 1996.

Hewitt, AE. (1998). New Zealand Soil Classification (2nd ed., Landcare Research Science Series No. 1). Lincoln: Manaaki Whenua Press.

Holmes, RL. (1983). Computer-assisted quality control in tree-ring dating and measurement. Tree-Ring Bulletin, 43, 69-78.

Jansen, HS. (1962). Depletion of carbon-13 in young kauri trees. Nature, 196(1), 84-85. 
Jouzel, J, Masson-Delmotte, V, Cattani, O, Dreyfus, G, Falourd, S, Hoffman, G, Minster, B, Nouet, J, Barmola, JM, Chappellaz, J, Fischer, H, Gallet, JC, Johnsen, S, Leuenberger, M, Loulergue, L, Luethi, D, Oerter, H, Parrenin, F, Raisbeck, G, Raynaud, D, Schilt, A, Schwander, J, Selmo, E, Souchez, R, Spahni, R, Stauffer, B, Steffensen, J P, Stenni, B, Stocker, TF, Tison, JL, et al. (2007). Orbital and millenial Antarctic climate variability over the past 800,000 years. Science, 317, 793-796. doi:10.1126/science.1141038.

Leavitt, SW. (2010). Tree-ring C-H-O isotope variability and sampling. Science of the Total Environment, 408, 5244-5253.

Lee, DE, Bannister, JM, \& Lindqvist, JK. (2007). Late Oligocene-Early Miocene leaf macrofossils confirm a long history of Agathis in New Zealand. New Zealand Journal of Botany, $45,565-578$.

Loader, NJ, Young, GHF, McCarroll, D, \& Wilson, RJS. (2013). Quantifying uncertainty in isotope dendroclimatology. The Holocene. doi:10.1 177/ 0959683613486945.

Madgwick, HAl, Oliver, G, \& Holten-Anderson, P. (1982). Above-ground biomass, nutrients, and energy content of trees in a second-growth stand of Agathis australis. New Zealand Journal of Forestry Science, 12(1), 3-6.

McCarroll, D, \& Loader, NJ. (2004). Stable isotopes in tree rings. Quaternary Science Reviews, 23, 771-801.

McCarroll, D, \& Pawellek, F. (2001). Stable carbon isotope ratios of Pinus sylvestris from northern Finland and the potential for extracting a climate signal from long Fennoscandian chronologies. The Holocene, 11(5), 517-526.

McConchie, D. (1999). Quality native timber from future managed stands. In W. Silvester \& R. McGowan (Eds.), Native Trees for the Future: potential, possibilities, problems, The University of Waikato, 8-10 October 1999 (pp. 15-19). Hamilton, Waikato: The University of Waikato.

Mildenhall, DC. (1985). Middle quaternary pollen diagrams from Judgeford, Lower Hutt and the significance of kauri pollen in a herbacious assemblage. New Zealand Geological Survey Research Notes, 8, 76-81.

Mitchell, ND. (1991). The derivation of climatic surfaces for New Zealand and their application to the biocllimatic analysis of the distribution of kauri (Agathis australis). Journal of the Royal Society of New Zealand, 21, 13-24.

Morrison, FT. (1955). Nursery propogation of kauri at Waipoua Forest. New Zealand Journal of Forestry, 7(2), 42-52.

Morrison, FT, \& Lloyd, RC. (1972). Articifical establishment of New Zealand kauri at Waipoua. New Zealand Journal of Forestry, 17(2), 264-273.

Niinemets, U, Sparrow, A, \& Cescatti, A. (2005). Light capture efficiency decreases with increasing tree age and size in the southern hemisphere gymnosperm Agathis australis. Trees, 19, 177-190. doi:10.1007/s00468-004-0379-y.

NIWA. (2012a). National Climate Maps. https://www.niwa.co.nz/climate/nationaland-regional-climate-maps/national. Accessed 31st May 2013.

NIWA. (2012b). Northland. https://www.niwa.co.nz/climate/national-and-regionalclimate-maps/northland. Accessed 6th May 2013.

Norton, DA. (1998). Impacts of coring on indigenous trees. Conservation Advisory Science Notes (Vol. 186). Wellington: Department of Conservation.

Ogden, J, \& Stewart, GH. (1995). Community Dynamics of the New Zealand Conifers. In N. J. Enright \& R. S. Hill (Eds.), Ecology of the Southern Conifers. Melbourne: Melbourne University Press.

Ogden, J, Wilson, A, Hendy, C, \& Newnham, RM. (1992). The Late Quaternary history of kauri (Agathis australis) in New Zealand and its climatic significance. Journal of Biogeography, 19, 611-622.

Ogden, J, Newnham, RM, Palmer, JG, Serra, RG, \& Mitchell, ND. (1993). Climatic implications of macro and microfossil assemblages from late Pleistocene deposits in northern New Zealand. Quaternany Research, 39, 107-109.

Oosterbaan, RJ. (n.d). SegReg: segmented linear regression with breakpoing and confidence intervals. http://www.waterlog.info/segreg.htm.

Oosterbaan, RJ, Sharma, DP, Singh, KN, \& Rao, KVGK. (1990). Crop production and soil salinity: Evaluation of field data from India by segmented linear regression with breakpoint. In Symposium on Land Drainage for Salinity Control in Arid and Semi-Arid Regions, Cairo, Egypt, 1990 (Vol. 3, pp. 373-383).

Palmer, JG, Lorrey, A, Turney, CSM, Hogg, A, Baillie, M, Fifield, K, \& Ogden, J. (2006). Extension of New Zealand kauri (Agathis australis) tree-ring chronologies into Oxygen Isotope Stage (OIS) -3. Journal of Quaternary Science, 21(7), 779-787.

Pardy, GF, Bergin, DO, \& Kimberley, MO. (1992). Survey of native tree plantations (FRI Bulletin Vol. 175). Rotorua: Forest Research Institute.

Petit, JR, Jouzel, J, Raynaud, D, Barkov, NI, Barnola, J-M, Basile, I, Bender, M, Chappellaz, J, Davis, M, Delaygue, G, Delmotte, M, Kotlyakov, V, Legrande, M, Lipenkov, VY, Lorius, C, Pepin, L, Ritz, C, Saltzman, E, \& Stievenard, M. (1999). Climate and atmospheric history of the past 420, 000 years from the Vostok ice core, Antarctica. Nature, 399, 429-436.
Porter, TJ, Pisaric, MFJ, Kokelj, SV, \& Edwards, TWD. (2009). Climatic signals in $\delta^{13} \mathrm{C}$ and $\delta^{18} \mathrm{O}$ of tree-rings from white spruce in the Mackenzie Delta region, northern Canada. Arctic Antarctic and Alpine Research, 41(4), 497-505.

R-Core-Team. (2012). R: A language and environment for statistical computing. Vienna, Austria: R Foundation for Statistical Computing.

Robertson, I, Rolfe, J, Switsur, VR, Carter, AHC, Hall, MA, Barker, AC, \& Waterhouse, JS. (1997a). Signal strength and climate relationships in 13C/12C ratios of tree ring cellulose from oak in southwest Finaland. Geophysical Research Letters, 24(12), 1487-1490.

Robertson, I, Switsur, VR, Carter, AHC, Barker, AC, Waterhouse, JS, Briffa, KR, \& Jones, PD. (1997b). Signal strength and climate relationships in 13C/12C ratios of tree ring cellulose from oak in east England. Journal of Geophysical Research (Atmospheres), 102(D16), 19507-19516.

Sackville-Hamilton, NR, Matthew, C, \& Lemaire, G. (1995). In defence of the $-3 / 2$ boundary rule: a re-evaluation of self-thinning concepts and status. Annals of Biology, 76, 569-577.

Schleser, $\mathrm{GH}, \&$ Jayasekera, R. (1985). $\delta^{13} \mathrm{C}$ variations of leaves in forests as an indication of reassimilated $\mathrm{CO}_{2}$ from the soil. Oecologia, 64, 536-542.

Stephens, DW, Silvester, WB, \& Burns, BR. (1999). Difference in water-use efficiency between Agathis australis and Dacrycarpus dacrydioides are genetically, not environmentally, determined. New Zealand Journal of Botany, 32(2), 361-367.

Steward, GA. (1999). The potetial for establishment and management of New Zealand native hardwood trees. In W. Silvester \& R. McGowan (Eds.), Native Trees for the Future: potential, possibilities, problems, University of Waikato, 8-10 October 1999 (pp. 40-44). Hamilton, Waikato: University of Waikato.

Steward, GA. (2011). Growth and yield of New Zealand kauri (Agathis australis (D (don) Lindl.)). Christchurch, New Zealand: Master of Forestry Science, University of Canterbury.

Steward, GA, \& Beveridge, E. (2010). A review of New Zealand kauri (Agathis australis (D.Don) Lindl.): its ecology, history, growth and potential for management for timber. New Zealand Journal of Forestry Science, 40, 33-59.

Steward, GA, \& Kimberley, MO. (2002). Heartwood content in planted and natural second-growth New Zealand kauri (Agathis australis). New Zealand Journal of Forestry Science, 32(2), 181-194.

Steward, GA, \& McKinley, RB. (2005). Plantation-grown New Zealand Kauri: a preliminary study of wood properties. New Zealand Journal of Forestry Science, 35(1), 35-49.

Steward, GA, Bergin, DO, \& Winstanley, WJ. (2003). Two records of kauri regeneration from trees planted south of the species' natural range. New Zealand Journal of Forestry Science, 33(1), 3-9.

Stewart, K. (2008). Kauri. Auckland: Penguin.

Treydte, K, Frank, DC, Saurer, M, Helle, G, Schleser, GH, \& Esper, J. (2009). Impact of climate and $\mathrm{CO}_{2}$ on a millenium-long tree-ring carbon isotope record. Geochimica et Cosmochimica Acta, 73(16), 4365-4647.

Turney, CSM, Fifield, LK, Hogg, AG, Palmer, JG, Hughen, K, Baillie, MGL, Galbraith, R, Ogden, J, Lorrey, A, Tims, SG, \& Jones, RT. (2010). The potential of New Zealand kauri (Agathis australis) for testing the synchronicity of abrupt climate change during the Last Glacial Interval (60,000-11,700 years ago). Quaternary Science Reviews, 29, 3677-3682.

Unknown. (1964). Kauris at North Taieri. Forest and Bird, 151(Feb), 11.

Unknown. (2001). Medicinal waters of Wairongoa Springs. New Zealand Botanical Society Newsletter, 65,15

Waipara, NW, Hill, S, Hill, LMW, Hough, EG, \& Horner, IJ. (2013). Surveillance methods to determine tree health, distribution of kauri dieback disease and associated pathogens. New Zealand Plant Protection, 66, 235-241.

Walcroft, AS. (1994). Aspects of stable carbon isotope variation in tree foliage and wood. Hamilton: Master of Science, University of Waikato.

Walcroft, AS, Whitehead, D, Kelliher, FM, Arneth, A, \& Silvester, WB. (2002). The effects of long-term, partial shading on growth and photosynthesis in Pinus radiata D. Don trees. Forest Ecology and Management, 163, 151-163.

Wardle, J. (2011). Wardle's Native Trees of New Zealand and their Story. Wellington: New Zealand Farm Forestry Association.

Wunder, J, Fowler, AM, Cook, ER, Price, M, \& McCloskey, SPJ. (2013). On the influence of tree size on the climate-growth relationship of New Zealand kauri (Agathis australis): insights from annual, monthly and daily growth patterns. Trees, 27(4), 937-948. doi:10.1007/s00468-013-0846-4.

doi:10.1186/s40490-014-0014-7

Cite this article as: Brookman et al:: Raised in the wild south: a dendrochronological and dendrochemical profile of a far-southern stand of kauri (Agathis australis) on the Taieri Plain, Otago. New Zealand Journal of Forestry Science 2014 44:14. 